\title{
MEASURING HEALTH-RELATED QUALITY OF LIFE: A COMPARISON BETWEEN PEOPLE LIVING WITH AIDS AND POLICE ON ACTIVE DUTY
}

\author{
Paul H Möller \\ D Phil (Sociology), University of the Free State \\ Professor, Department of Sociology, North-West University \\ Corresponding author: sosphm@puknet.puk.ac.za
}

\section{Ria Smit}

D Litt et Phil (Sociology), Rand Afrikaans University

Senior Lecturer, Department of Sociology, Rand Afrikaans University

Key words: HIV/AIDS; health-related quality of life; police on active duty; SF-36 questionnaire; subjective wellbeing

\begin{abstract}
The escalating rate of AIDS-related deaths in South Africa has led to an increase in social scientific research on the perceptions and experiences of people suffering from AIDS by focusing on their physical health and emotional well-being. The aim of this study was to measure and compare the quality of life of two sample groups in South Africa, namely members of the police on active duty, as an example of a healthy population, and people living with AIDS. The SF-36 questionnaire was used as measuring instrument to assess the respondents' perceptions of their own health-related quality of life. From the research, which was based on a comparative approach, it was found that statistically significant differences existed between people living with AIDS and members of the police force in respect of their scores on all eight of the SF-36 domains $(p<0.05)$. The biggest difference between the AIDS respondents and members of the police occurred in the emotional roles limitation dimension, followed by the physical functioning and the bodily pain dimensions. Intervention programmes that are aimed at contributing to the improvement of the well-being of people suffering from AIDS, therefore need to incorporate mechanisms that provide support in all eight of the quality-of-life dimensions.
\end{abstract}

\section{OPSOMMING}

Die styging in die getal VIGS-verwante sterftes in Suid-Afrika het gelei tot ' $n$ toename in sosiaalwetenskaplike navorsing oor die persepsies en belewenisse van mense met VIGS, met die fokus op hul fisieke gesondheid en emosionele welsyn. Die doel van hierdie studie was om die lewenskwaliteit van twee groepe in Suid-Afrika te meet en met mekaar te vergelyk. Hierdie twee groepe het enersyds uit lede van die polisie in aktiewe diens, as voorbeeld van 'n gesonde populasie en andersyds uit mense met VIGS bestaan. Die SF-36-vraelys is as meetinstrument gebruik om die respondente se persepsies van hul gesondheidsverwante lewenskwaliteit te assesseer. Op grond van hierdie navorsing, wat op 'n vergelykende benadering berus het, is bevind dat mense met VIGS en lede van die polisiemag se onderskeie tellings op al agt SF-36-domeine $(p<0.05)$ beduidend verskil het. Die grootste verskil tussen die persepsies van die respondente met VIGS en dié van lede van die polisiemag het op die emosionele rolbeperkingsdomein gelê, gevolg deur die domeine van fisieke funksionering en liggaamlike pyn. Dit is dus noodsaaklik dat intervensieprogramme wat die welsyn van VIGS-lyers wil bevorder, meganismes moet inkorporeer wat ondersteuning in al agt lewenskwaliteitsdomeine bied. 


\section{INTRODUCTION}

Health-related quality of life is of great significance across the whole spectrum of the human health continuum. Numerous studies have shown that the assessment of quality of life does not only shed light on the life experiences of people with acute illnesses, but that it may be of particular importance to people who suffer from chronic diseases. In view of the fact that there is no adequate cure or vaccine for HIV/AIDS, AIDS has become one of the most feared chronic and life-threatening diseases of our time. According to the World Health Organisation (WHO) and the Joint United Nations Programme on HIV/AIDS (UNAIDS), approximately 30 million people all over the world had been infected with the HI-virus in December 1999 (WHO, 2003:1). By December 2002, this figure had escalated to 42 million people, with an estimated 16,000 to 17,000 new HIV infections per day (LifeLine SA, 2003:33; WHO, 2003:1).

What is even more alarming, is that $66 \%$ of the global population infected with HIV is situated in subSaharan Africa - accounting for $83 \%$ of the world's AIDS-related deaths (WHO, 2003:2). In South Africa alone, reports indicate that 4.7 million people are HIVpositive (LifeLine SA, 2003:30). According to the Women's International Network News (2001:1) the number of people with HIV infections in South Africa may grow to 6.1 million by 2005 and 7.5 million by 2010.

Although various studies have focused on the quality of life of people living with HIV/AIDS (cf. Demmer, 2001; Joshi, Nau \& Kalsekar, 2001; Molassiotis, Callaghan, Twinn \& Lam, 2001; Sherman, 2001), the widespread occurrence of HIV infections in South Africa underlines the importance of continued research on the impact of HIV/AIDS on the dimensions of quality of life, in this country in particular. Furthermore, there is a significant lacuna in the literature in the comparative data on the health-related quality of life of people living with AIDS and that of a population of healthy individuals. This article is based on the results of two recent quantitative studies which had attempted to fill this gap in the literature by posing the following question: What is the difference between the quality of life (subjective well-being) of members of the police force on active duty (as an example of a healthy population) and that of people living with AIDS? (The concept police on active duty refers to those members of the police who are actively involved in combatting crime and who carry firearms when on duty (Möller \& Petr, 2002:10)).

\section{LITERATURE REVIEW: MEASURING HEALTH-RELATED QUALITY OF LIFE}

In recent developments in the Sociology of Health and Illness, the scope of investigations has moved from a social scientific view which had focused primarily, and in some cases exclusively, on different aspects of being in a state of ill health, to a perspective which seeks to position both health and illness, in a social, cultural and behavioural context (Weiss \& Lonnquist, 1997:1). According to the World Health Organisation health can be defined as "a state of complete physical, mental and social well-being, and not merely the absence of disease and infirmity" (Gilbert, Selikow \& Walker, 1996:7; Kendall, 2002:404). In congruence with this definition of health, health-related quality of life indicators generally incorporate physical, mental, emotional, and social aspects of both health perception and function (Irvine, 1993:22). Health-related quality of life can therefore be seen as the health dimension of quality of life that constitutes "a subjective evaluation of various aspects of one's life" (Demmer, 2001:482), "...a composite descriptor applied to an unlimited spectrum of tangible and intangible parameters of life satisfaction and capacity" (Irvine, 1993:22). The measurement of health-related quality of life is therefore a subjective assessment of one's well-being - a perception of the degree of contentment with and capability to perform and control all the facets of one's life (Molassiotis et al. 2001:319).

In the past, researchers and medical practitioners have relied on disease-specific evaluations to assess a patient's health-related quality of life before and after medical intervention. It is only during the past 20 years that a more generic approach to measuring a person's health status has been developed (Shapiro \& Richmond, 1996:196). A number of these generic measuring self-reported instruments have been tested with regard to a wide variety of diseases, of which the 36-item short-form health questionnaire (SF-36) is considered one of the best (Shapiro \& Richmond, 1996:196; Joshi et al. 2001:136). 
The SF-36 questionnaire, which has been documented in more than 2000 publications, proved to be very useful for measuring the health-related quality of life (HRQOL) of general and specific populations, patients with acute and chronic diseases in clinical practice in various situations and under different circumstances (Ware, 2001:1). In their appraisal of health-related quality of life instruments Joshi et al. (2001:136) found that the SF-36 questionnaire ".. fared better than all its counterparts. The instrument has minimal respondent burden and ... appears to be most optimal for HRQOL measurement...", in particular in HIV/AIDS patients.

The SF-36 questionnaire, which is directed towards the respondents' experiences, feelings, beliefs and convictions about their health-related quality of life during the past four weeks, consists of eight scales and two summary measures (physical and mental health). The eight multi-item-scales that were used, are: (a) limitations in physical activities because of health problems; (b) limitations in social activities because of physical or emotional problems; (c) limitations in role activities because of physical health problems; (d) bodily pain; (e) general mental health; (f) limitations in role activities because of emotional problems; (g) vitality; and (h) general health perceptions (Ware \& Sherbourne, 1992:473-483).

Ware (2001:1-2) indicates that a factor analysis of data from the medical outcomes study (MOS) on the general population of the United States of America, which used the SF-36 questionnaire, confirmed that physical and mental health factors, as measured by the eight dimensions of the questionnaire, account for as much as between $80 \%$ and $85 \%$ of the variance in the respondents' perceptions of their healthrelated quality of life. Studies of the general populations in both Sweden and the United Kingdom resulted in similar findings. From the above studies it is evident that three scales, namely the physical functioning, physical roles limitation and bodily pain dimension scales, correlate most highly with the physical component of health-related quality of life. In addition, the mental health component of subjective quality of life correlates most highly with the general mental health, emotional roles limitation and social functioning scales. The vitality, general health perception and social functioning scales have significant correlations with both the physical and mental health components (Ware,
2001:1-2).

The content validity of the SF-36 questionnaire is confirmed by systematic comparisons that indicate that this questionnaire includes eight of the most frequently represented health concepts in the measurement of health-related quality of life (Ware, 2001:3). Both the internal and construct validity of the SF-36 instrument have also been confirmed through numerous studies that utilised this questionnaire (cf. Petr, 2000; Petr, 2001; Möller \& Petr, 2002; Strassnig, Brar \& Ganguli, 2003).

It is, therefore, understandable that, since the development of the SF-36 questionnaire, several studies have made use of this instrument to assess the healthrelated quality of life of individuals suffering from different ailments (cf. Mapes, Lopes, Satayathum \& McCullough, 2003; Patti, Cacopardo, Palermo \& Ciancio, 2003). Yet, owing to the subjective nature of individuals' experiences and definitions of their realities, indicators relating to subjective quality of life or subjective well-being (how satisfied a person is with his/her life as a whole) have, to a great extent, been left in abeyance. Against the backdrop of this brief theoretical overview of the measurement of healthrelated quality of life, some of the findings of two quantitative studies on health-related quality of life, which are based on a comparative approach, are discussed below.

\section{HEALTH-RELATED QUALITY OF LIFE OF MEMBERS OF THE POLICE FORCE AND PEOPLE LIVING WITH AIDS: A COMPARI- SON}

Sociology attempts to develop a better understanding of those aspects of social behaviour that may impact on social relationships, role performances, construction of reality and quality of life. Being involved in a high-risk occupation such as policing, or suffering from a deadly disease such as AIDS may, therefore, be seen as examples of social 'realities' that could influence the subjective perception of one's quality of life. In an attempt to contribute to this body of knowledge, the aim of the study can be summarised as follows:

- to compare, measure and explore the health-related quality of life of members of the police force 
on active duty and people living with AIDS by using the eight multi-item domains of the SF-36 questionnaire.

\section{Research design and profile of respond- ents}

In order to achieve the above aim, data from the following two quantitative studies, which both made use of the validated SF-36 questionnaire, were used:

(a) The health-related quality of life of members of the police force on active duty in Potchefstroom, North-West Province, conducted in June 2001 (Möller \& Petr, 2002:11) (sample size $=70$ ). (In the study by Möller and Petr (2002:10), a comparison was made between the health-related quality of life of police on active duty in two countries, viz. Ceské Budéjovice, Czech Republic and in Potchefstroom, South Africa. For the purposes of the study reported in this article, only the data regarding the HRQOL of the members of the police in Potchefstroom were used).

(b) The health-related quality of life of people suffering from AIDS residing in Potchefstroom, North-West Province, conducted in November 2002 (sample size $=43$ ). These respondents are involved in the Tshepong AIDS Project of Potchefstroom. The recruitment of the respondents was undertaken by the HIV/AIDS programme coordinator at the North-West University (Potchefstroom campus).

For the purposes of the two studies, the SF-36 questionnaire was translated into Afrikaans (Möller, Petr, Vurm, Soukupova \& Vondrous, 2002:4-9) and into Tswana (Zerwick, Möller, Petr, Vurm, Kalova, Soukupova \& Vondrous, 2002:40-45).

In both these studies, a purposive or judgmental sampling method, a non-probability sampling technique (cf. Babbie, 2002:447), was used. Before the respondents' health-related quality of life was assessed, an overview was given of the aim of this study and each individual was assured of his/her anonymity, and that the use of the data would be strictly confidential. In accordance with research ethics, this assurance was given by the fieldworker who either informed the respond- ents verbally of these conditions or by means of the covering letter that accompanied the questionnaire.

The following three tables give an overview of the respondents' profile regarding the variables gender, age and educational qualifications. Table 1 on next page.

It is evident from Table 1 that the majority of the respondents, who were members of the police force in Potchefstroom, are men (80\%). Of the respondents in the AIDS sample, 30 of the 43 respondents were women $(70 \%)$, whereas only 13 were men. The latter profile must be seen against the following background: Although the results of South African 2001 census showed that the North-West Province had more or less an equal gender distribution of $50,6 \%$ women compared to $49,4 \%$ men (Statistics South Africa, 2003), women are considered to be more vulnerable to HIV infection than men (Evian, 2000:193). The Nelson Mandela/HSRC study (Shisana \& Simbayi, 2002:20) which conducted an investigation into the prevalence of HIV/AIDS in South Africa, for example, found that "...women have higher HIV prevalence than men [because]... women's reproductive systems make it easier for them to be infected with HIV, and [that] men are more effective at transmitting the human immunodeficiency virus".

Table 2 shows that the majority of the respondents who were members of the police on active duty $(73 \%)$ were between the ages of 26 and 35 years, whereas the majority of the AIDS sample group (58\%) were 30 years old, and younger. According to the 2001 South African population census, the age group 15 to 34 years represented $36,3 \%$ of the total population in the North-West Province (Statistics South Africa, 2003). According to existing data on South Africa, the age group with the highest HIV/AIDS prevalence is that of (persons aged between) 25 and 29 (Shisana \& Simbayi, 2002:7).

According to Table 3, the majority of the police on active duty sample group (72\%) had a grade 12 certificate as highest educational qualification. Nineteen per cent of the respondents of this sample group were in possession of a tertiary education qualification. Of the AIDS respondents, $39 \%$ had a primary education up to grade 7 . Only $26 \%$ of the respondents had com- 
Table 1: Gender profile of the police on active duty and the AIDS sample groups

\begin{tabular}{|l|l|l|l|l|}
\hline Gender & \multicolumn{2}{|l|}{ Police on active duty respondents } & \multicolumn{2}{l|}{ AIDS respondents } \\
\hline & $\mathbf{n}$ & $\%$ & $\mathbf{n}$ & $\%$ \\
\hline Male & 56 & $80 \%$ & 13 & $30 \%$ \\
\hline Female & 14 & $20 \%$ & 30 & $70 \%$ \\
\hline Total & 70 & $100 \%$ & 43 & $100 \%$ \\
\hline
\end{tabular}

Table 2: Age profile of the police on active duty and the AIDS sample groups

\begin{tabular}{|l|l|l|l|l|}
\hline Age & \multicolumn{2}{|l|}{ Police on active duty respondents } & \multicolumn{2}{l|}{ AIDS respondents } \\
\hline & $\mathbf{n}$ & $\%$ & $\mathbf{n}$ & $\%$ \\
\hline$<\mathbf{2 1}$ & - & - & 3 & $7 \%$ \\
\hline $\mathbf{2 1 - 2 5}$ & 5 & $7 \%$ & 10 & $23 \%$ \\
\hline $\mathbf{2 6 - 3 0}$ & 23 & $33 \%$ & 12 & $28 \%$ \\
\hline $\mathbf{3 1 - 3 5}$ & 28 & $40 \%$ & 12 & $28 \%$ \\
\hline $\mathbf{3 6 - 4 0}$ & 6 & $8 \%$ & 2 & $5 \%$ \\
\hline $\mathbf{4 1 - 4 5}$ & 4 & $6 \%$ & 1 & $2 \%$ \\
\hline $\mathbf{4 6 - 5 0}$ & 1 & $1 \%$ & 1 & $2 \%$ \\
\hline $\mathbf{5 1 - 5 5}$ & 3 & $4 \%$ & 2 & $5 \%$ \\
\hline Total & 70 & $100 \%$ & 43 & $100 \%$ \\
\hline
\end{tabular}

Table 3: Education profile of the police on active duty and the AIDS sample groups

\begin{tabular}{|c|c|c|c|c|}
\hline \multirow[t]{2}{*}{ Education } & \multicolumn{2}{|c|}{ Police on active duty respondents } & \multicolumn{2}{|c|}{ AIDS respondents } \\
\hline & $\mathbf{n}$ & $\%$ & $\mathbf{n}$ & $\%$ \\
\hline No formal schooling & - & - & 1 & $2 \%$ \\
\hline $\begin{array}{l}\text { Grade 1-7 } \\
\text { (Grade 1- Std.5) }\end{array}$ & - & - & 17 & $39 \%$ \\
\hline Grade 8-11 (Std. 6-9) & 6 & $9 \%$ & 14 & $33 \%$ \\
\hline Grade 12 (Std. 10) & 50 & $72 \%$ & 11 & $26 \%$ \\
\hline Diploma & 10 & $14 \%$ & - & - \\
\hline Degree & 3 & $4 \%$ & - & - \\
\hline Postgraduate qualification & 1 & $1 \%$ & - & - \\
\hline Total & 70 & $100 \%$ & 43 & $100 \%$ \\
\hline
\end{tabular}


pleted their secondary education.

The two studies that focused on the quality of health of members of the police on active duty in Potchefstroom (Möller \& Petr, 2002:11), and people suffering from AIDS respectively, are both case studies because of the detailed and in-depth nature of the recordings regarding the respondents' physical, psychological and social well-being. The data which was gathered historic-specifically from these two groups and which had been based on an ideographic approach, made it possible to explore and describe the interrelation between (a) variables indicating a subjective quality of life; and (b) variables relating to an objective reality as manifested in the respondents' physical, psychological and social well-being.

\section{Hypothesis}

The following hypothesis was formulated by taking the eight multi-item domains of the SF-36 questionnaire as a point of departure:

There is a difference of health-related quality of life between police on active duty and people living with HIV/AIDS.

In order to test this hypothesis, the data was analysed by using a factor analysis and $t$-tests. The latter was used to compare the difference between the means of the different groups on a $5 \%$ level of significance (cf. Mitchell \& Jolley, 2001:211-213), where the null hypothesis refers to the equality of means ( $H_{0}: \mu_{1}=\mu_{2}$ ) tested against the two-sided alternative $\left(H_{A}: \mu_{1} \neq \mu_{2}\right)$.

\section{Findings and discussion}

The factor analyses of both studies confirm that the items of the SF-36 questionnaire are well-described by the extracted factors and that construct validity therefore exists. The following findings, which were based on a factor pattern analysis of the perceived health-related quality of life of the respondents in the two samples, came to the fore:

- Among members of the police on active duty, Factor 1 correlates most highly with the bodily pain $(0.80498)$, mental health $(0.79442)$, vitality
(0.72143), and social functioning (0.44538) scales. Factor 2 correlates most highly with the emotional roles limitation (0.53938), general health $(0.57477)$, and physical roles limitation $(0.57086)$ scales. The physical functioning scale $(-0.09407)$ does not fit into either of the two clusters. The variance explained by Factor 1 is 3.0379992 and by Factor 2 is 1.4588260 . The final communality value for the eight scales is 4.496825 .

- Among people living with AIDS, Factor 1 correlates most highly with the physical functioning (0.86134), emotional roles limitation (0.83928), mental health $(0.78995)$, and physical roles limitation (0.51071) scales. Factor 2 correlates most highly with the general health $(0.84887)$, vitality (0.66407), social functioning (0.64697), and bodily pain (0.57002) scales. The variance explained by Factor 1 is 3.3308601 and by Factor 2, 2.3613138. The final communality value for the eight scales is 5.692174 .

The fact that the two samples are independent of each other, with unequal variances and that the same SF36 measuring instrument was used in both studies, made it possible to use $t$-tests to compare the two groups' scores on the eight scales (domains) of the SF-36. Figure 1 is a comparison between the perceptions of the respondents who are members of the police and people who are suffering from AIDS regarding their health-related quality of life in terms of the eight SF-36 domains.

From Figure 1, it is evident that the respondents suffering from AIDS have attained observably lower scores in all eight domains and are less satisfied with their health-related quality of life than the respondents who are members of the police force. The biggest observable difference between the two groups is in the emotional roles limitation domain (for example, feeling depressed) (31\%), followed by the extent to which bodily pain is experienced (20\%) and the physical functioning domain (18\%) (the extent to which vigorous activities can be carried out).

The respondents' experiences of their health-related quality of life will now be discussed. 
Figure 1: Comparison between members of the police on active duty and people living with AIDS in respect of their perceptions of their quality of life

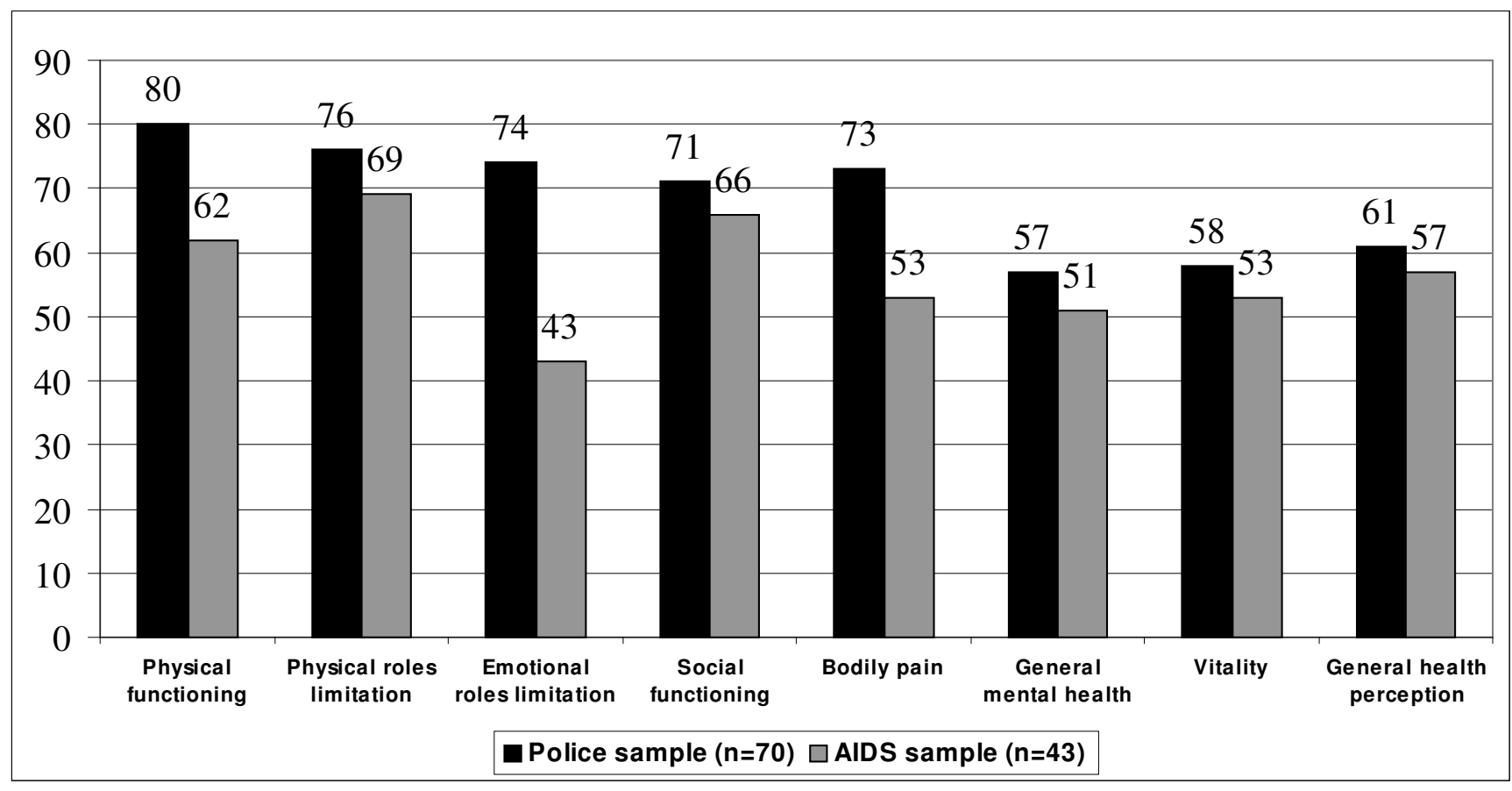

\section{The physical functioning domain}

The scores on the physical functioning domain scale indicate the extent to which the respondents' perceptions of their quality of life are influenced by their physical condition. In the first place, physical functioning refers to the extent to which the respondents are able to perform vigorous activities such as running, lifting heavy objects, participating in strenuous sports, climbing several flights of stairs and walking more than a kilometre. In the second place, it entails the performance of moderate activities such as bending, kneeling or stooping, bathing and dressing themselves. The research hypothesis is accepted on the following grounds: there is an observable difference of $18 \%$ between the perceptions of the AIDS respondents $(62 \%)$ and those of the members of the police on active duty (80\%) (cf. Möller \& Petr, 2002:13). The $t$ test conducted on the scores of the two groups on the physical functioning scale shows that statistically significant differences also exist between the AIDS respondents and police on active duty $(p=3.406)$. These findings correspond with medical evidence that shows that AIDS patients (even as early as the first few weeks of acquiring the HIV infection) may experience extreme levels of tiredness, muscle and joint pains, nausea, fever, and chest pain that may impede their ability to perform physical tasks (Evian, 2000:28, 32).

Depending on how far the disease had advanced, people suffering from AIDS could be assisted, inter alia, by family members, friends, primary health-care workers, voluntary and non-governmental associations such as the Tshepong Aids Project in Potchefstroom and the National Association of People Living with AIDS in engaging in light exercises.

\section{The physical roles limitation domain}

The physical roles limitation domain refers to the extent to which respondents' performance of their roles in daily activities is impeded by their physical state of health. For example, their ability to perform vigorous activities such as lifting heavy objects or to perform moderate activities such as moving a table or pushing a vacuum cleaner (cf. Ware, Bayliss, Mannocchia \& Davis, 1999:2). The results reveal that, in their experience of how the performance of roles is limited by their physical condition, a $7 \%$ observable difference exists between AIDS respondents (69\%) and the police on active duty sample (76\%) (cf. Möller \& Petr, 2002:14). Once again the research hypothesis is accepted. Statistically significant differences also exist 
between the AIDS respondents and members of the police on active duty $(p=1.113)$. These results confirm the research conducted by Molassiotis et al. (2001:320) who found that HIV/AIDS patients experience difficulty in their physical role functioning, in particular in their day-to-day and career-related responsibilities.

The limitation to perform roles often results in people questioning the value of their lives (Sherman, $2001: 10)$. By means of anticipatory socialisation, people living with AIDS can prepare themselves for possible future (disruptive) changes to their lives, for example, as a result of ill-health. This could be achieved with the assistance of primary health-care workers and voluntary and non-governmental associations (Anderson \& Taylor, 2001:440). Guidance can also be given in respect of role exit, viz. to disengage from a role that is central to one's self-identity and the reestablishment of an identity in a new role that takes into account one's previous role(s) (Wallace \& Wolf, 1999:50-51).

\section{The emotional roles limitation domain}

The assessment of this domain gives an indication of the extent to which the emotional condition of the respondents, for example, feeling depressed or anxious, limits their daily functioning and ability to perform roles, such as in cutting down on the amount of time spent on work or other activities and accomplishing less than they would like to. From the respondents' scores that were based on this dimension of their health-related quality of life, it is clear that there is observable difference between the AIDS respondents (31\%) and the sample of police on active duty (74\%) (cf. Möller \& Petr, 2002:14). In addition, a $t$-test shows that statistically significant differences exist between the AIDS respondents and the police on active duty $(p=4.419)$ in respect of the emotional roles limitation domain. Regarding this quality of life domain, the research hypothesis can therefore be accepted. These findings also correspond with the research done by Molassiotis et al. (2001:320) in that HIV/AIDS patients' emotional functioning change as a result of their ill-health and that they often experienced depression, anxiety and/ or anger.

When people suffering from AIDS report their experience of physical changes, there is usually a reciprocal cycle of associated emotional alterations. "Uncertainty becomes a chronic and pervasive source of psychological distress, particularly as it relates to ambiguous symptom patterns, exacerbation and remissions of symptoms, and the fear of stigma and ostracism. Such uncertainty is linked with negative perceptions of quality of life and poor psychological adjustment. As a result, patients with AIDS are at risk for psychological disorders, such as depression and anxiety" (Sherman, $2001: 8)$. With the aid of family members, friends, and health-care workers, emotional support could be given to AIDS sufferers, thus helping them to redefine their situation and develop emotional and problem-oriented coping strategies, which may contribute to a more positive experience of quality of life (cf. Sherman, 2001:8). (Redefinition of one's situation, according to Theodorson and Theodorson (1970:105), is when "... an individual examines and evaluates a situation prior to deciding what attitudes and behaviour are appropriate").

Positive emotions, such as hope, enable a person to deal with situations in which needs and goals cannot be met (Akinsola, 2001:159, 160). If motivational and emotional support for people suffering from AIDS is neglected, it could lead to a psychological malaise that is rooted in alienation (cf. Mills, 1968:xvi-xvii). Alienation implies the experience of a feeling of powerlessness, a loss of meaning (Berger \& Luckmann, 1966:3), a loss of control, isolation (separation and detachment from respondents' groups), and self-estrangement (the inability to find self-rewarding activities in which to engage oneself) (cf. Seeman, 1959:784-790). This may, in turn, be detrimental to their quality of life.

\section{The social functioning domain}

In this context, social functioning refers to social activities and interaction with significant others such as family members, friends, neighbours and other social relations. A comparison between the AIDS respondents (66\%) and the police on active duty sample $(71 \%)$ indicates that an observable difference, although minimal $(5 \%)$, exists between these two groups' perceptions of their social functioning. Statistically significant differences also exist between the respondents suffering from AIDS and the members of the police on active duty ( $p=1.195)$. In respect of the social functioning domain, the research hypothesis can therefore be accepted. 
One of the basic assumptions of sociology is that all human beings are social by nature. In fact, according to the Christian faith, God created people to love and care for one another (cf. Genesis 2:18). It is, therefore, crucial to the well-being of people suffering from AIDS that family members, friends and health-care workers pay attention to the social functioning domain in order to establish a sense of cohesion and the experience of security. Sherman (2001:13), for example, is of the opinion that "patients with AIDS enhanced the quality of their lives through the support of family, their partners, health-care providers, and God".

\section{The bodily pain domain}

The results of the bodily pain dimension of the SF-36 questionnaire indicate to what extent the respondents' experience of bodily pain hinders their performance of daily activities, including work-related duties in the public domain and tasks within the home environment. (The items are ranked on the scale ranging from none, very mild, mild, moderate, severe to very severe). A $20 \%$ observable difference in the bodily pain domain exists between the AIDS sample (53\%) and the police on active duty sample (73\%) (cf. Möller \& Petr, 2002:15). In addition, the results of a $t$-test indicate that statistically significant differences exist between these two groups $(p=3.820)$. These findings correspond with medical evidence that indicates that AIDS patients, due to opportunistic infections, may experience extreme levels of pain and discomfort in some cases. (Evian, 2000:28, 32; Molassiotis et al. 2001:325), which affect their overall functioning.

The experience of bodily pain inhibits the performance of roles and influences one's social functioning and emotional condition. To illustrate this, Sherman (2001:8) maintains that general estimates of the prevalence of bodily pain in HIV/AIDS-infected individuals range between $25 \%$ and $80 \%$. Notwithstanding the existence of medical schemes, it is important to stress that sufficient and affordable medical treatment needs to be made available by the health care system in general, and the South African government in particular, to those who are suffering from severe bodily pain.

\section{The general mental health domain}

Theorists such as Rose, Pugh, Lears and Gordon (1998:295) and Molassiotis et al. (2001:329) report sig- nificant mood disturbances as well as a low sense of mental well-being among AIDS patients. In the reported study, however, the perceptions of AIDS respondents' $(51 \%)$ of their general mental health condition (for example, feeling full of pep, being happy, feeling calm and peaceful, being very nervous, or feeling worn out and tired) are not notably lower than the perceptions of the members of the police force (57\%) (Möller \& Petr, 2002:17). However, according to the results of a $t$-test, statistically significant differences exist between the AIDS sample and police on active duty sample $(p=$ 1.657). The research hypothesis can, therefore, be accepted.

If support is not given to people living with AIDS, in order to improve their mental well-being, it may jeopardise their social functioning (for example, social activities and interaction with family and friends) as well as their social role performance (Ezzy \& De Visser, 1998:196).

\section{The vitality domain}

Rose et al. (1998:299) are of the opinion that fatigue is a significant source of morbidity and a loss of vitality in people living with AIDS, which may have an impact on both their daily functioning and quality of life. Regarding the vitality domain of the SF-36 (for example, feeling energetic and full of pep, or worn out and tired), the hypothesis is accepted, notwithstanding the fact that only a small difference of $5 \%$ exists between the AIDS sample (53\%) and the police on active duty sample (58\%) (Möller \& Petr, 2002:17). Once again, various support systems, such as significant others and health-care workers could possibly provide effective assistance to improve the quality of life of people suffering from AIDS.

\section{The general health perception domain}

Demmer (2001:484) reports that the AIDS respondents in his study rated health-related worries as one of their biggest quality of life concerns. This finding is supported by the fact that a difference of $4 \%$ exists between the AIDS respondents' (57\%) self-evaluation of their general health condition and that of the respondents who are police on active duty (61\%). Once again, the research hypothesis is accepted. The respondents' perception of their general health is measured in terms of concepts such as excellent, very good, good, fair or poor, getting ill easier than other people, 
and just as healthy as anyone they know. A $t$-test reveals that, in the general health perception domain, statistically significant differences exist between the sample of people living with AIDS and the sample of members of the police on active duty $(p=1.385)$.

\section{Limitations of the research}

When the possible limitations of the research are considered, the sample size of the AIDS group comes to the fore. Although the sample of people living with HIV/AIDS is relatively small, this sample may serve as an exemplar of people who suffer from this disease.

\section{CONCLUSION AND RECOMMENDATIONS}

The aim of this study was to explore, measure and compare, by means of the eight multi-item domains of the SF-36 questionnaire, the quality of life of people living with AIDS and members of the police on active duty in Potchefstroom, South Africa. It was found that statistically significant differences exist between the two sample groups in their scores on all eight of the scales of the SF-36 questionnaire. This implies that the perceptions of people suffering from AIDS differ significantly from the perceptions of the members of the police force regarding the eight dimensions of their health-related quality of life, viz. physical functioning, role limitations due to physical, as well as emotional problems, social functioning, bodily pain, general mental health, vitality and general health perception.

More specifically, the respondents suffering from AIDS attained lower scores in all eight of the SF-36 domains and are less satisfied with their health-related quality of life than the sample of police on active duty. The greatest difference between the AIDS respondents and members of the police force exists in the emotional roles limitation dimension (31\%), followed by the physical functioning (18\%) and the bodily pain (20\%) dimensions.

Friedland, Renwick and McColl $(1996: 17,22)$ found that providing social support and assistance to people living with AIDS in the development of coping strategies are important resources in alleviating the stress experienced by these people. They also found "... that people with a serious illness such as AIDS adjust their expectations to life and, as a result, may view their quality of life somewhat positively". The research conducted by Rabkin, Remien, Katoff and Williams (1993:162) confirms this in that the quality of life of AIDS patients may even be enhanced, if these patients receive support from others in the process of developing coping strategies. These findings thus emphasise the importance of research such as the comparative study between the members of the police on active duty and people suffering from AIDS, in developing a better understanding of the eight different dimensions measured with the SF-36 instrument, as experienced and perceived by people living with AIDS.

For the South African population to respond effectively, a comprehensive understanding of the AIDS pandemic is of vital importance (Shisana \& Simbayi, 2002:19). The solution, offered by the World Health Organization (WHO), for unsafe sexual intercourse, and the devastating consequences thereof, includes a combination of methods of preventing HIV/AIDS by means of media campaigns, testing and counselling, school programmes, the treatment of sexually transmitted diseases, and the provision of anti-retroviral drugs (Pienaar, 2002:14). The current South African national AIDS strategy for the prevention of AIDS concurs with that of the WHO by emphasising the promotion of safe sex; improving the management and control of sexually transmitted infections; providing voluntary counselling and testing; addressing issues related to blood transfusion and HIV; reducing motherto-child HIV transmission and providing appropriate post-exposure services (Shisana \& Simbayi, 2002:21).

In addition to the services rendered in accordance with the propagated AIDS prevention strategies, existing intervention programmes directed at improving the quality of life of people living with AIDS, ought to be implemented and creative new cost-effective programmes developed. However, in order for all intervention programmes to be effective and the role of civil society, voluntary and non-governmental associations to be successful in enhancing an individual's physical, psychological and social well-being, they need to reflect changes in values, norms (for example, only one sex partner), social structures (for example, the implementation of the current South African national 
AIDS strategy for the prevention of AIDS), facilities (for example, changes in the provision of voluntary counselling, anti-AIDS medicine) and attitudes toward people living with HIV/AIDS.

"It is not the HIV virus which is killing me or making my life not worth living, but the bad attitude of people towards me and their rejection of me" (a person with HIV/ AIDS, quoted by Evian (2000)).

\section{REFERENCES}

AKINSOLA, HA 2001: Fostering hope in people living with AIDS in Africa: The role of primary health-care workers. Australian Journal of Rural Health, 9:158-165.

ANDERSON, ML \& TAYLOR, HF 2001: Sociology: The essentials. Belmont: Wadsworth.

BABBIE, E 2002: The basics of social research. Belmont: Wadsworth. BERGER, PL \& LUCKMANN, T 1966: The social construction of reality. New York: Doubleday.

DEMMER, C 2001: Quality of life and risk perception among predominantly heterosexual, minority individuals with HIV/AIDS. Aids Patient Care and STDs, 15(9):481-489.

EVIAN, C 2000: Primary AIDS care. A practical guide for primary health care personnel in the clinical and supportive care of people with HIV/AIDS. Houghton: Jacana Education.

EZZY, D \& DE VISSER, R 1998: Employment, accommodation, finances and combination therapy: The social consequences of living with HIV/AIDS in Australia. AIDS Care, 10(3):189-199.

FRIEDLAND, J; RENWICK, R \& MCCOLL, M 1996: Coping and social support as determinants of quality of life in HIV/AIDS. Aids Care, 8(1):15-31.

GILBERT, L; SELIKOW, T \& WALKER, L 1996: Society, health and disease. An introductory reader for health professionals. Randburg: Ravan.

IRVINE, EJ 1993: Quality of life: Rationale and Methods for Developing a Disease-Specific Instrument for Inflammatory Bowel Disease. Scandinavian Journal of Gastroenterology Supplement, 28(1):2227.

JOSHI, AV; NAU, DP \& KALSEKAR, IK 2001: An appraisal of healthrelated quality of life (HRQOL) instruments for use in patients infected with Human Immunodeficiency Virus (HIV) Disease. Value in Health, 4(2):136.

KENDALL, D 2002: Sociology in our times: The essentials. Belmont: Wadsworth.

LIFELINE SOUTH AFRICA 2003: Basic HIV training. Johannesburg: LifeLine.

MAPES, DL; LOPES, AA; SATAYATHUM, S \& MCCULLOUGH, KP
2003: Health-related quality of life as a predictor of mortality and hospitalization: The dialysis outcomes and practice patterns study (DOPPS). Kidney International, 64(1):339-349.

MILLS, CW 1968: White collar: The American middle classes. London: Oxford University Press.

MITCHELL, M \& JOLLEY, J 2001: Research design explained. Fort Worth: Harcourt.

MOLASSIOTIS, A; CALLAGHAN, SF; TWINN, SF \& LAM, SW 2001: Correlates of quality of life in symptomatic HIV patients living in Hong Kong. AIDS Care, 13(3):319-334.

MÖLLER, PH \& PETR, P 2002: Measuring health-related quality of life: A comparison between police on active duty in Ceske Budejovice, Czech Republic and Potchefstroom, Republic of South Africa. Acta Criminologica, 15(1):9-22.

MÖLLER, PH; PETR, P; VURM, V; SOUKUPOVA, A \& VONDROUS, P 2002: Afrikaans version of the SF-36 questionnaire.

Kontakt Supplementum (Czech Republic), 4(1):4-9.

PATTI, F; CACOPARDO, M; PALERMO, F \& CIANCIO, MR 2003: Health-related quality of life and depression in an Italian sample of multiple sclerosis patients. Journal of the Neurological Science, 211(1/2):55-62.

PETR, P 2000: Dotazník SF-36 o kvalite zivota podmínené zdravím [The SF-36 questionnaire in the assessment of health-related quality of life]. Kontakt, 2(1):26-29.

PETR, P 2001: Kvalita zivota u príslusníku Policie Ceské Republiky. Vyuzití dotazníku SF-36 v praxi [Health-related quality of life of Czech police members on active duty. A practical use of the SF-36 questionnaire]. Proceedings of a clinical seminary, regional hospital of South Bohemia, Ceské Budéjovice, Czech Republic, 19 September 2001:13.

PIENAAR, A 2002: Gesondheid se weegskaal. Beeld, 14, Oct. 31:14. RABKIN, JG; REMIEN, R; KATOFF, L \& WILLIAMS, JB 1993: Resilience in adversity among long-term survivors of AIDS. Hospital and Community Psychiatry, 44(2):259-265.

ROSE, L; PUGH, LC; LEARS, K \& GORDON, DL 1998: The fatigue experience: Persons with HIV infection. Journal of Advanced Nursing, 28(2):295-304.

SEEMAN, M 1959: On the meaning of alienation. American Sociological Review, 24(1):783-791.

SHAPIRO, ET \& RICHMOND, JC 1996: The use of a generic, patient-based health assessment (SF-36) for evaluation of patients with anterior cruciate ligament injuries. American Journal of Sports Medicine, 24(2):196-200.

SHERMAN, DW 2001: The perceptions and experiences of patients with AIDS: Implications regarding quality of life and palliative care. Journal of Hospice and Palliative Nursing, 3(1):7-16.

SHISANA, O \& SIMBAYI, L 2002: Nelson Mandela/HSRC study of HIV/AIDS: South African National HIV prevalence, behavioural risk and mass media. Executive summary. Pretoria: HSRC. 
STATISTICS SOUTH AFRICA 2003: Census 2001. (Online: http:// www.statssa.gov.za)

STRASSNIG, M; BRAR, JS \& GANGULI, R 2003: Body mass index and quality of life in community-dwelling patients with schizophrenia. Schizophrenia Research, 62(1/2):73-76.

THEODORSON, GA \& THEODORSON, AG 1970: A modern dictionary of sociology. New York: Crowell.

WALLACE, RA \& WOLF, A 1999: Contemporary sociological theory: Expanding the classical tradition. Upper Saddle River: Prentice Hall. WARE, JE 2001: The SF-36 Health Survey. (Online: http://www.s36.com 27).

WARE, JE; BAYLISS, M; MANNOCCHIA, M \& DAVIS, GL 1999: Health-related quality of life in chronic hepatitis $C$ : Impact of disease and treatment response (Online: http://www.qualitymetric.com/sf36). WARE, JE \& SHERBOURNE, CD 1992: The MOS 36-Item ShortForm Health Survey (SF-36). Conceptual framework and item selection. Medical Care, 30(6):473-483.

WEISS, GL \& LONNQUIST, LE 1997: The sociology of health, healing and illness. Upper Saddle River: Prentice Hall. WOMEN'S INTERNATIONAL NETWORK NEWS 2001: HIV/AIDS: South Africa cases could total 7.5 million by 2010. (Online: http:// www.unfoundation.org).

WORLD HEALTH ORGANISATION (WHO) 2003: Fact Sheet 2. The global HIV/AIDS epidemic. (Online: http://www3.who.int).

ZERWICK, J; MÖLLER, PH; PETR, P; VURM, V; KALOVA, H; SOUKUPOVA, A \& VONDROUS, P 2002: Tswana version of the SF-36 questionnaire. Kontakt Supplementum (Czech Republic), $4(1): 40-45$. 